\title{
The South China Sea and the Building of a National Maritime Culture
}

\author{
A New Chinese Province in the Making
}

\begin{abstract}
This article investigates the nationalistic rhetoric disseminated by the Chinese political elite regarding the South China Sea, exploring how this political discourse contributed to building a collective consciousness of the sea among Chinese citizens and to creating a new maritime province.
\end{abstract}

KEYWORDS: South China Sea, China, Southeast Asia, nationalism, territorialization

\section{INTRODUCTION}

Research on the South China Sea dispute ${ }^{1}$ has highlighted how this issue affects bilateral and multilateral relations in the region, directly involving countries with deep economic ties such as the People's Republic of China (PRC), the Philippines, Vietnam, and Malaysia.

China is probably the most influential actor in this scenario, in both diplomatic and strategic terms. Since the second half of the I970s, approximately the inception of Deng Xiaoping's era, Beijing has developed a clear policy toward the South China Sea that has progressively influenced the

Alessandro Uras is a Teaching Fellow in International Politics of Asia in the Department of Social Sciences and Institutions, University of Cagliari, Italy. He wishes to thank Filippo Menga for the opportunity to present a paper at the October 2016 workshop at the University of Manchester, Interdisciplinary Workshop on Water, Technology and the Nation-State, from which this article was developed. Email: <alessandro.uras@unica.it>.

I. A partial list of contributions to this topic would include Mark J. Valencia, Jon M. van Dyke, and Noel Ludwig, Sharing the Resources of the South China Sea (The Hague: Martinus Nijhoff, 1997); Ralf Emmers, Geopolitics and maritime territorial disputes in East Asia (London: Routledge, 20Io); Leszek Buszynski, "Rising Tensions in the South China Sea: Prospects for a Resolution of the Issue," Security Challenges 6:2 (Winter 20IO), pp. 85-IO4; and Zou Keyuan, "China's U-Shaped Line in the South China Sea Revisited," Ocean Development \& International Law 43:I(20I2), pp. I8-34.

Asian Survey, Vol. 57, Number 6, pp. I008-I03I. ISSN o004-4687, electronic ISSN I533-838X. (C) 2017 by The Regents of the University of California. All rights reserved. Please direct all requests for permission to photocopy or reproduce article content through the University of California Press's Reprints and Permissions web page, http://www.ucpress.edu/journals.php?p=reprints. DOI: https:// doi.org/IO.I525/AS.20I7.57.6.1008. 
strategies of other claimants to the disputed region. The occupation of the Spratly Islands started in the same period, and this process continued, slowly but steadily, through the years. By the early 2000 almost the entire archipelagic area was subject to physical control efforts by one claimant state.

China claims a large part of the South China Sea, and it is not willing to reconsider or discuss its position. The Chinese leadership is convinced that the integrity of what it sees as national territory is sacred and indisputable. Any step back from this stance might have dramatic consequences for public opinion. The South China Sea is not yet considered a core national security issue by the Chinese Communist Party (CCP), the way Taiwan and Tibet are, but its strategic and economic significance have become pivotal in the Chinese political agenda.

In this specific aspect, the CCP needed to present the South China Sea situation in a different way, with a proper narration and dialectic. The Party has emphasized the importance of the contested waters not only in terms of access to the resources and to the sea lanes of communication (SLOCs) but also in terms of national justice, because the South China Sea is asserted to be part of Chinese territory. To implement this strategy, the ruling elite is attempting to use the past to realign the nation's identity toward the sea, portraying the ancient Celestial Empire as an intrinsically peaceful maritime power.

The historical voyages of Zheng He, a renowned fleet admiral under the Ming Dynasty in the early fifteenth century, constitute the founding myth of the Chinese maritime tradition. The year 2005 marked the 6ooth anniversary of Zheng He's journeys of diplomacy, trade, and discovery. Manipulating the mythology around his famed exploits has helped Beijing reorient its citizens toward the sea, instilling in them a sense of mission and an artificial maritime heritage. As ruling elites manipulate identity and culture, they generate expectations about how the nation-state will conduct itself in domestic and international settings. This process generated higher awareness among China's citizens but also strong criticism toward the status quo in the South China Sea, which became a question of primary national interest. Beijing is attempting to use the past to build an identity and a Chinese maritime culture specifically to fit today's exigencies, but also to direct it effectively into growing domestic popular cognitions.

This article examines how this patriotic propaganda, and the consequent creation of a maritime heritage, have enabled Beijing to manage the issue at 
its own pace and with strong popular support. Although China has not traditionally been a regional maritime power, its South China Sea strategy has progressed to the extent that it can now be considered the hegemonic force in the area. This article aims to illustrate how China developed its strategy of nationalization and territorialization of the South China Sea. Thus the analysis of the PRC's maritime strategy is tied to a historical account of the Chinese presence there.

Our exploration unfolds in several parts in order to analyze the origins and possible outcomes of such a maritime posture. The first part gives a theoretical framework, with reference to theories of territory and territorialization, ${ }^{2}$ naval nationalism, ${ }^{3}$ and water nationalism, ${ }^{4}$ which aims to clarify the hypothesis about the progressive territorialization of the South China Sea. The second part focuses on the nature of Beijing's maritime claims there. The third describes the building of a maritime collective memory based on the mythology surrounding Zheng He's journeys, exploring the purposes of those campaigns. The article intends to show how the modern-day Chinese elite created an artificial but ready-made maritime heritage to reinforce the country's position in the South China Sea, redirecting mounting popular nationalism via these issues.

\section{WATER NATIONALISM AND THE TERRITORIALIZATION OF THE SOUTH CHINA SEA}

The Chinese claim to the South China Sea is the result of a daring fusion of domestically and internationally oriented rhetoric. The historical representation of China's millennial presence, and the consequent maritime expansion

2. See Robert D. Sack, "Human Territoriality: A Theory," Annals of the Association of American Geographers 73:I (198I), pp. 55-74; Claude Raffestin, "Territoriality: A Reflection of the Discrepancies between the Organization of Space and Individual Liberty," International Political Science Review 5:2 (1984), pp. 139-I46; and Alexander Murphy, "Entente territorial: Sack and Raffestin on Territoriality," Environment and Planning D: Society and Space 30:I (2012), pp. 159-172.

3. See Robert S. Ross, "China's Naval Nationalism: Sources, Prospects, and the U.S. Response," International Security 34:2 (2009), pp. 46-8I; and Colin S. Gray, The Navy in the Post-Cold War World: The Uses and Value of Strategic Seapower (University Park: Pennsylvania State University Press, 1994).

4. See Jeremy Allouche, Water Nationalism: An Explanation of the Past and Present Conflicts in Central Asia, the Middle East and the Indian Subcontinent, doctoral dissertation, Institut universitaire de hautes études internationales, Geneva, 2005. 
of the concept of sacred territory, work in tandem. As argued by the realist scholar Hans Morgenthau, Beijing's evolving approach to the dispute has progressively attenuated the distinction between domestic and foreign policy, so much so that they have become identical. Regarding the specific case of the South China Sea, domestic politics should be problematized, as it can indeed influence international politics, and vice versa. ${ }^{5}$ The state should not be taken as a monolithic unit of analysis, hence the domestic-foreign polarity will be misleading when analyzing such multifaceted dynamics.

As pointed out by Filippo Menga, the most analytically significant aspect for our focus is the emphasis on how physical space can be socially and politically constructed. In this setting, Beijing's South China Sea policy represents a manifold body of strategy in which the two political realms influence their respective outputs. The measures and decisions adopted by the Chinese government will necessarily have both domestic and foreign consequences, despite their internal origin.

This strategy might represent a clear example of Robert Putnam's idea of interrelation between the two levels: "National governments seek to maximise their own ability to satisfy domestic pressures at the international level, while minimising the adverse consequences of foreign developments." 6 China's most important, but also most difficult, target is to maintain a strong domestic commitment without jeopardizing its relationships with its coastal neighbors. Consequently, the South China Sea rhetoric serves as a domestic paradigm, corroborated by the mythologizing of Zheng He, but it also represents an international statement of indisputable sovereignty over the Sea's islands and the surrounding waters.

China is not only claiming and fighting for the control of the waters, but to reiterate its inalienable ownership. The South China Sea is considered by Beijing to be effectively a part of Chinese national territory. How has China developed its strategy and exercised its power? In this section I analyze the Chinese maritime policy through a different theoretical lens, to test our hypothesis about the progressive territorialization of the South China Sea.

5. Filippo Menga, "Domestic and International Dimensions of Transboundary Water Politics," Water Alternatives 9:3 (2016): 204.

6. Robert D. Putnam, "Diplomacy and Domestic Politics: The Logic of Two-Level Games," International Organization 42:3 (1988): 434. 


\section{ABANDONING THE MAINLAND: THE INCEPTION OF CHINA'S SEA CULTURE}

Robert Ross provides an interesting insight regarding the geopolitical scope of the Chinese strategy. He defines "naval nationalism" as "one manifestation of prestige strategies, whereby governments seek international success to bolster their domestic popularity." ${ }^{\prime \prime}$ Ross also underlines that nations should be considered as land or sea powers not because of cultural or historical predispositions but because of enduring geopolitical circumstances. Following the naval nationalism approach, China is reorienting its policy toward the sea due to geopolitical circumstances and not because of a historical inclination.

China's appetite for resources is directly connected with control of the SLOCs in the South China Sea, which is now a security imperative for the government. Naval nationalists also argue that the main security interests should include maritime sovereignty and the protection of imports of natural resources. Concurrently, China must revive its maritime power and strengthen the "nation's maritime culture." Despite its purported maritime historical heritage and culture, in geopolitical terms China is clearly a continental power.

Zheng He's expeditions might be deemed a demonstration of this assumption. After the reign of Emperor Yongle (I405-33), Zheng He's fleet, sometimes said to total hundreds of ships and nearly 30,000 persons, was called home and abandoned in Nanjing Harbor. Moreover, the eunuch admiral's expeditions were China's only attempt at sea power, underscoring Ming's preference for the safety of its continental frontiers. ${ }^{8}$ China never experienced true maritime supremacy, and the aforementioned maritime culture applies more to the geostrategic realm. However, the emergence of a maritime rebranding process based on Zheng He's accomplishments might be analyzed in different terms using a geopolitical lens.

\section{TERRITORY AND TERRITORIALITY IN CHINA'S QUEST FOR MARITIME SOVEREIGNTY}

Before starting the analysis of the South China Sea, it is necessary to highlight the importance of the territory, especially in its symbolic dimension, for the

7. Robert S. Ross, "China's Naval Nationalism: Sources, Prospects, and the U.S. Response," International Security 34:2 (2009): 50.

8. Ibid., 56. 
Chinese party-state. The whole idea of territory in the scholarly context has undergone a transformation in the last decades. It has shifted from a purely material interpretation, as an exploitable resource, to a broader one taking into account its relational and complex nature. Territory is a living subject, shaped and enriched by the constant interaction between environment and human settlement. The South China Sea has been idealized as in effect part of the Chinese national territory and, despite its oceanic range, is perceived and portrayed by the Chinese government in the same way as land. The historical background of Beijing's claim and the dialectic forged on Zheng He's benevolent journeys represent the empirical backbone of this assumption.

Jeremy Allouche's work on water nationalism might apply to our case because of the unique features of the South China Sea issue. According to Allouche, the nationalization of water can be analyzed through the nationbuilding process, specifically as declared sovereignty over natural resources amid a willingness to make state territory national. ${ }^{9}$

To adapt this theory to the territorialization of the South China Sea, it is necessary to clarify a few basic concepts. First, the concept of territoriality is central in the development of the contemporary concept of the state. Starting from a geographic standpoint, territory is portrayed as a social construct created by the constant human modification of the land. Therefore, the idea of territoriality indicates the evolving relationship between people and environment, a bridge between societies and the ecological and anthropological world aimed at achieving the highest level of social autonomy. In other words, the process of territorialization builds on the human freedom to transform the human living environment. Robert Sack defines territoriality as "the attempt to affect, influence, or control action, interactions, or access by asserting and attempting to enforce control over a specific geographic area." ${ }^{\prime 10}$ Sack's definition is particularly relevant in outlining China's "accessand-control” strategy in the South China Sea. In Sack's thinking, territoriality is a core element in the construction of social and political space, which also influences the general perception of that space by civil society. Therefore, society's perception of the national territory is an evolving process rather than fixed condition.

9. Allouche, Water Nationalism, II4.

Io. Robert D. Sack, "Human Territoriality: A Theory," Annals of the Association of American Geographers 73:I (198I), 55. 
Drawing from Sack's observation, territoriality is a concept that necessarily varies over space and time and today is closely connected to the conceit of sovereignty. This connection becomes particularly significant in analyzing Chinese sovereignty over the South China Sea. Beijing put together its own idea of territoriality, based on the Party's ongoing quest for domestic legitimacy, in which the South China Sea has progressively become an unquestionable pillar. Accordingly, the Chinese self-declared sovereignty over the South China Sea is (for them) indisputable and non-negotiable.

Steven Grosby outlines territoriality as a "transcendental, primordial feature" of almost all societies. ${ }^{11}$ In his theory, territoriality is constituted from a variety of factors. He underlines the physical characteristic of the land, how the land is conceived by those who live within the territory, and the popular consciousness of these bounded patterns of relationship. Allouche states that "territoriality has become the most important pillar of state control around the world.... The link to the water is quite obvious since water has become a constitutive part of this territorial process." ${ }^{12}$

Territory and the concept of territoriality are fundamental prerequisites of any nation-building process and or nationalistic project. Following the theoretical path shaped by Benedict Anderson, in which the nation is pictured as an imagined political community, we might define the nation as a social and cultural construct with limited spatial and demographic extent. ${ }^{13}$

This spatial extension - the Chinese case is paradigmatic - is not a fixed and immutable parameter; it might vary depending on domestic circumstances and political needs. Accordingly, the idea of nationalism has been shaped by the evolution of the CCP and by the necessity to preserve partystate legitimacy, especially after the 1989 Tiananmen crisis. Zhang Ming stated that "the nationalist wave in China is a spontaneous public reaction to a series of international events, not a government propaganda." ${ }^{14}$ But, as suggested by Zhao Suisheng, the Chinese nationalist eruption might also be viewed as a top-down process dictated by the Communist leadership.

II. Steven Grosby, "Territoriality: The Transcendental, Primordial Feature of Modern Societies," Nations and Nationalism I:2 (1995), I49.

I2. Allouche, "Water Nationalism," 94.

13. Benedict Anderson, Imagined Communities (London: Verso, I99I), 7.

I4. Ming Zhang, "The New Thinking of Sino-US Relations: An Interview Note," Journal of Contemporary China, I4:6 (1997): II7-23. 
Western isolation and the post-Tiananmen economic sanctions against China played an important role in shaping a sense of wounded national pride, coupled with a clearer notion of how China was perceived in the global arena. But the Party was immersed in this dynamic: it directed and enacted some important maneuvers to bolster nationalism. After the end of the bi-polar confrontation, Beijing suffered a dangerous internal legitimacy crisis because of the rapid fall of international communism.

The CCP's response focused on the exploitation of mounting nationalism, underlining the distinctive characteristics of Chinese culture and its historical heritage. The main expression of this effort was the launch of the patriotic education campaign in 1992. According to Zhao Suisheng, "The patriotic education campaign was a state-led nationalist movement, which redefined the legitimacy of the post-Tiananmen leadership in a way that would permit the Communist Party's rule to continue on the basis of a non-Communist ideology." 15 The emergence of a presumed international conspiracy against China's greatness, the perpetuation of Western imperialism and the memory of the "century of humiliation" under foreign control shaped the domestic dialectic in a way that is still relevant, especially in debating the South China Sea issue.

\section{THE SOUTH CHINA SEA: A LIQUID TERRITORY}

Regarding the process of nationalization of the South China Sea, this article considers primarily the republican years (1912-49). Despite the importance of the imperial age, which will be dealt with in the following sections, the process of nation-building started with the foundation of the Republic of China in 19I2. Allouche defines the nation-building process as an emotionally constructed structure intended to give the nation strong control over the entirety of its territory. The author delineates two ways to achieve a proper level of control, and they both apply to the Chinese process. The first way is to make the state territory national by constructing national identity according to state boundaries. The building of maritime pride and the inception of Maritime Day in 2005 allowed China to create a modern seafaring national identity, which fits with the historical boundaries that Beijing has drafted into 
service in the South China Sea. These boundaries are now an integral part of the dialectics of the masses and they are perfectly integrated into the nationalistic rhetoric and identity. Strong emotional attachment to the territory is embedded in Chinese tradition, due the fundamental principle of the inviolability of the sacred territory of the PRC.

This doctrine was fueled by important military personalities such as Wu Shengli, former People's Liberation Army Navy admiral and commander of the South Sea Fleet, who stated that China is an oceanic nation endowed by nature with a long coastline, many islands, and jurisdiction over a massive sea area. Admiral Wu asked Chinese citizens to raise their collective consciousness of the sea, bringing about "the great revitalization of the Chinese nation."16

The second way to make the territory national is to get recognition from the international community. In this regard Allouche clarifies that water is assimilated to the land, with each state declaring its full sovereignty over water within the national territory. ${ }^{17}$ This assumption is particularly accurate when analyzing the "scramble" for the South China Sea, with five countries asserting their sovereignty over a variable portion of sea.

But this latter option is less feasible for China; very few countries recognize, or abstain from criticizing, its position. International recognition is important but not essential for the Chinese government, as long as it is able to maintain a favorable status quo in the disputed waters.

Going forward in the analysis, Allouche's first option is probably the most suitable to corroborate my hypothesis. Reinforcing the relationship between national identity and boundaries is not more important than gaining international recognition, but it is an essential step. Accordingly, the party-state developed a new and wider concept of national territory and territoriality, in which the South China Sea is one of the most important national priorities.

As pointed out by David Knight, "It is human beliefs and actions that give territory meaning." 18 The Chinese government enforced a set of social and political actions that influenced the population's values and their perception of the national territory. Recalling Sack's definition of territoriality, the first Chinese attempt to enforce its control over the South China Sea goes back to

I6. James Holmes and Toshi Yoshihara, Red Star over the Pacific: China's Rise and the Challenge to US Maritime Strategy (Annapolis: Naval Institute Press, 20I0), I8.

I7. Allouche, "Water Nationalism," I23.

I8. David Knight, "Identity and Territory: Geographical Perspectives on Nationalism and Regionalism," Annals of the Association of the American Geographers 72:4 (1982), 517. 
1947. After the end of the Second World War, Chiang Kai-shek and his officials started to redefine the national territory by drawing and updating maps and borders. In 1947 the Kuomintang government drew the so-called U-shaped line, which was composed of II dashes and included a maritime area approximately $\mathrm{I}, 800 \mathrm{~km}$ from north to south and $900 \mathrm{~km}$ from east to west. An immense area of ocean, more than two-thirds of the South China Sea, was claimed and declared to be under Chinese sovereignty.

As pointed out by Zerilli, a physical space can be transformed into a political one at any time, but it might also return to its natural form if not properly engaged by political action. The unilateral act behind the U-shaped line allowed China to define its own indisputable borders in the South China Sea and marked the beginning of its long-standing claim over this specific geographic area. The U-shaped line still represents the main expression of Chinese power in the region. Symbolically, the line has moved beyond a simple claim of sovereignty to encompass Beijing's self-declared historical rights of exploration and exploitation of resources, fishing, and navigation. Furthermore, the drawing of the line may be seen as the starting point of a process of nationalization and territorialization of the waters. This process has been strengthened over the decades, producing even more results in recent years.

In June 2012 the Chinese government raised the administrative status of the Macclesfield Bank and the Paracel and Spratly Islands from a county-level administrative office to a prefecture-level entity named Sansha, with administration operating from Woody Island in the Paracels archipelago. ${ }^{19}$ In July the People's Liberation Army Navy established a new garrison in Sansha, which is a military sub-district with administrative duties. It is responsible for supporting the military work conducted by the municipality such as conscription and national defense mobilization tasks. ${ }^{20}$ Its main significance is not military; it is a political decision to demonstrate Chinese sovereignty over the South China Sea.

The establishment of the garrison also reflects an administrative upgrade, meant to show Beijing's complete control of the territory. The territorialization process also depends on rigorous and programmatic control over natural

I9. "China Raises Administrative Status of South China Sea Islands," Global Times, June 2I, 20I2, $<$ http://www.globaltimes.cn/content/716392.shtml>.

20. Dennis J. Blasko and M. Taylor Fravel, "Much Ado about the Sansha Garrison," The Diplomat, August 23, 20I2, <http://thediplomat.com/20I2/o8/much-ado-about-the-sansha-garrison/>. 
resources. China exercises its sovereignty even if it is not internationally recognized, planning and publishing unilateral schedules of activities and fostering multilateral agreements. In the early 200os, Beijing's willingness to share subsoil resources was intended as a good-faith gesture toward the other claimants.

In 2004 the Philippines National Oil Company and the Chinese National Offshore Oil Company signed a three-year agreement for joint exploration over a $143,000 \mathrm{~km}^{2}$ sea area around the Spratlys. The agreement was intentionally left open for a third signatory, namely Vietnam's PetroVietnam, which joined in 2005. China's former openness on the exploitation of subsoil resources has now evolved into a more rigid stance, which also covers fishing activities. Beijing exercised its control over the territory by raising unilateral fishing bans, arresting foreign fishermen and seizing their boats. Meanwhile China enhanced the capability of its own fishing fleet, which is now able to operate in deep waters.

This supremacy gave the country the leading position in the management of fishing resources. According to the latest report from the United Nations Food and Agricultural Organization, China is expected to account for $38 \%$ of global fish consumption by 2030. ${ }^{21}$ This projection and the growing need for seafood led the Chinese government to be more assertive and expand its maritime capability even more.

On August 2, 20I6, a large fishing port was opened in Yazhou, a small city under the Sanya municipality on Hainan Island. The same day marked the end of the annual fishing ban imposed by China in the western part of the South China Sea. The new facility is also designed to work as a support base for exploiting fishery resources for Sansha. Zhang Huazhong, head of the Sanya Ocean and Fishery Bureau, remarked on the importance of the new port in safeguarding China's fishing rights in the South China Sea. China provided an extremely detailed spatial representation of its own South China Sea, drawing careful boundaries and disposing of the natural resources almost exclusively, but it also needed a proper narrative and a meaningful purpose to channel the rising patriotism toward this sensitive issue.

2I. World Bank, Fish to 2030: Prospect for Fisheries and Aquaculture, Agriculture and Environmental Services Discussion Paper 03, December 2013, <http://www.fao.org/docrep/org/i364oe/i3640 e.pdf>, accessed September 7, 2016. 


\section{HISTORY MATTERS: THE NATURE OF THE CHINESE CLAIMS IN THE SOUTH CHINA SEA}

The South China Sea covers an area of approximately 3.5 million $\mathrm{km}^{2}$, and is surrounded by a large number of littoral and insular states including Brunei, China, ${ }^{22}$ Indonesia, Malaysia, the Philippines, Singapore, and Vietnam. The waters are marked by a great number of islands, shoals, reefs, and rocks, which can be gathered into four major groups: Macclesfield Bank, Paracel Islands, Pratas Islands, and Spratly Islands. With its U-shaped line, China claims all of these islands and their surrounding waters. The Chinese government built the legitimacy of its claims on its historical usage of the waters, which provides alleged historical rights to this defined maritime space. ${ }^{23}$

On the basis of this paradigm, China refers to the South China Sea as the "sacred territorial waters" rightfully belonging to itself, saying that the islands have been part of Chinese territory from "time immemorial." ${ }^{24}$ According to Chinese records, the discovery of the Spratly Islands can be traced back to the Han Dynasty. Yang Fu, of the Eastern Han Dynasty (23-220 AD), made reference to the islands in his book, Record of Rarities (Yiwu Zhi) ${ }^{25}$ From the twelfth to the seventeenth century Chinese records make occasional reference to the islands, and during this period the Chinese Empire viewed itself as the center of a universal state which "oversaw a hierarchy of tributary states." Considering its indisputable superiority over coastal neighbors, the Celestial Empire had no reason to make any formal claim of sovereignty. The voyages of Zheng He, conducted between 1405 and I433, are probably the most important report of that period.

22. In this article, the term China includes both the People's Republic and Taiwan. This choice has been made because the two governments share the same position and the same claims in the South China Sea.

23. The notion of historical rights does not exist in the Law of the Sea, which China ratified in 1996, but Beijing appeals to an International Court of Justice ruling that there are special factors, notably traditional fisheries-related factors, that are capable of creating "historical rights" in maritime spaces.

24. Frederic Lasserre, "Once Forgotten Reefs... Historical Images in the Scramble for the South China Sea," Cybergeo: European Journal of Geography, 92 (1999), 4, <https://cybergeo.revues.org/5782>.

25. Ministry of Foreign Affairs, Peoples' Republic of China, "Historical Evidence to Support China's Sovereignty over Nansha Islands," November 17, 2000, <http://www.fmprc.gov.cn/mfa_ eng/topics_665678/3754_66606o/tr9231.shtml>, accessed August 22, 2016.

26. Lu Ning, The Spratly Archipelago: The Origins of the Claims and Possible Solutions (Washington, DC: International Center, 1993), 22. 


\section{CHINA'S TERRITORIAL STRUGGLE BEYOND THE CENTURY OF HUMILIATION}

The first formal act of sovereignty was performed in 1876 , when China's ambassador to the UK marked the Paracels as Chinese territory. ${ }^{27}$ The Middle Kingdom was progressively losing strength and influence: the breakout of the first Opium War in I839 is considered the beginning of the "century of humiliation" in Chinese historiography. In I9I4, with the empire already collapsed, a continuous boundary line enclosing part of the South China Sea appeared in a Chinese atlas compiled by two cartographers. Meanwhile, Japan was boosting its imperialist propaganda, and by the late 1930s had established a strong presence in the South China Sea, using the island of Itu Aba as a submarine base. The end of World War II and the Japanese surrender are considered a milestone for China's ambitions in the South China Sea. Despite the ongoing civil war (1945-49), the Kuomintang government issued a new atlas in 1947, drawing an II-dash line to indicate the geographical extent of its authority over the South China Sea.

In May 1949, all the islands were placed under the authority of the Hainan District of Guangdong Province. ${ }^{28}$ The founding of the People's Republic in October was a major shift for the country's political system. Regarding the South China Sea, the CCP simply confirmed the Kuomintang's claim. In August 1951, Chinese Foreign Minister Zhou Enlai stated: "The Paracel Islands and the Spratly Islands are inherently Chinese territory, just like the whole of the Pratas Islands and Macclesfield Bank. They fell during the war of aggression waged by Japanese imperialists, but were fully recovered by the then Chinese Government upon Japan's surrender." ${ }^{29}$

From a legal perspective, Article 2 of 195I Treaty of San Francisco states that Japan renounces all "right, title and claim to the Spratly Islands and to the Paracel Islands." ${ }^{30}$ China strongly appeals to this statement as proof of the legitimacy of its historical claims over the two archipelagos, but the document

27. Jon M. van Dyke and Dale L. Bennett, "Islands and the Delimitation of Ocean Space in the South China Sea," Ocean Yearbook Io (1993), 64.

28. Zhiguo Gao and Bing Bing Jia, "The Nine-Dash Line in the South China Sea: History, Status and Implications," American Journal of International Law IO7:I (2013): IO3.

29. Hanns Jurgen Buchholz, Law of the Sea Zones in the Pacific Ocean (Singapore: Institute of Southeast Asian Studies, 1987), 44.

30. United Nations, "Treaty of Peace with Japan (with Two Declarations). Signed at San Francisco, on 8 September 1951," United Nations Treaty Series, vol. 136, 50, <https://treaties.un.org/ doc/publication/unts/volume\%20136/volume-I36-i-1832-english.pdf>, accessed August 25, 2016. 
does not award any degree of sovereignty to any specific country. From the Chinese standpoint, any sovereignty clarification would be redundant because of its indisputable right to the islands.

The territorial controversy remained quiescent until the end of the 1970s, when the demands of the other claimants became more consistent. In 1988 China faced Vietnam in a serious clash, during which the PLA Navy sank three Vietnamese vessels and killed 72 people. In February 1992 China promulgated its Law on the Territorial Sea and the Contiguous Zone. Article 6 of the document states, "Foreign ships for non-military purposes shall enjoy the right of innocent passage through the territorial sea of the People's Republic of China... To enter the territorial sea of the People's Republic of China, foreign military ships must obtain permission from the Government of the People's Republic of China." ${ }^{31}$

The Chinese purported historical rule of the sea has been progressively bolstered with an irredentist legal literature. In June 1998 Beijing promulgated the Law on the Exclusive Economic Zone and the Continental Shelf, which also extended to the islands in the South China Sea. Reinforcing its claim, the government issued an influential document, "Historical Evidence to Support China's Sovereignty over Nansha [i.e., Spratly] Islands." ${ }^{32}$

\section{HISTORICAL RECORDS OR HISTORICAL REPRESENTATIONS?}

China has constantly reaffirmed its primacy in discovering, naming, developing, conducting economic activities on, and exercising jurisdiction over the Spratly Islands. The first two paragraphs of the aforementioned document give a detailed account of sailing activity during the Han, Tang, and Song dynasties, showing how Chinese seafarers and fishermen developed and shaped the maritime environment. The fishing activities and the construction of a certain number of ports are described in the I868 Guide to the South China Sea. According to the guide, "The footmarks of fishermen could be found in every isle of the Nansha Islands and some of the fishermen would even live there for a long period of time." ${ }^{33}$

31. Standing Committee of the National People's Congress, People's Republic of China, Law on the Territorial Sea and the Contiguous Zone of 25 February 1992, <http://www.un.org/depts/los/ LEGISLATIONANDTREATIES/PDFFILES/CHN_1992_Law.pdf>, accessed August 25, 2016.

32. Nansha Islands is the Chinese name for the Spratly Islands. The document was released on November 17, 2000, by the Chinese Ministry of Foreign Affairs.

33. Ministry of Foreign Affairs, "Historical Evidence." 
The third paragraph, which covers some jurisdictional issues, is perhaps the most challenging and interesting part of the document. The account starts with the assumption that the Spratly Islands have been under Chinese jurisdiction since the Yuan Dynasty (I27I-I368), corroborated by patrol and inspection activities led by the navy. During the Qing era (I644-I9II), the Spratlys were marked as Chinese territory in many maps, such as the Map of Administrative Divisions of the Whole China of 1724 and the Map of Unified China of the Great Qing for Ten Thousand Years of 1767, which also received an update in I8I7. This tendency continued during the early republican years and the inception of the PRC. The document ends with the unequivocal statement that China was the first to discover and develop the archipelago and put it under its jurisdiction and sovereignty. Thus, the Spratly Islands are seen as being an inalienable part of Chinese territory for centuries.

The legitimacy of this entire body of literature is still under evaluation by the scientific community, and some scholars are skeptical about the alleged historical evidence. For instance, Bill Hayton argues that the aforementioned I876 ambassador's claim never materialized. He writes that the document "was an entry in the ambassador's diary, not a formal diplomatic claim by a government." ${ }^{34}$ Mohan Malik underlines the existence of several contradictions in China's use of history to justify its claim in the South China Sea. In his words, "China's claim that its land boundaries were historically never defined and delimited stands in sharp contrast with the stance that China's maritime boundaries were always clearly defined and delimited." ${ }^{35}$

The main weakness of this statement is ascribable to the reference to a historical period, the imperial era, in which the whole concept of maritime sovereignty did not yet exist. Martin Jacques reiterates that "the idea of maritime sovereignty is a relatively recent invention, starting from 1945 when the United States declared that it intended to exercise sovereignty over its territorial waters." ${ }^{36}$

34. Bill Hayton, "When Good Lawyers Write Bad History: Unreliable Evidence and the South China Sea Territorial Dispute," Ocean Development \& International Law, 48:I (2017), p. 22.

35. Mohan Malik, "Historical Fiction: China’s South China Sea Claims," World Affairs, May/ June 20I3, <http://www.worldaffairsjournal.org/article/historical-fiction-china\%E2\%80\%99s-southchina-sea-claims $>$.

36. Martin Jacques, When China Rules the World: The Rise of the Middle Kingdom and the End of the Western World (London: Allen Lane, 2009), 292-93. 
This artificial historical representation, rather than a historiographic account, of the Chinese maritime past is linked to the wider territorialization process. If territoriality is an open process in which individuals' choices shape their relation with the space, even by appropriation, we might say that the Chinese government decided to produce a complex set of symbols to corroborate the physical occupation of the space. Accordingly, the territorialization of the South China Sea is determined by the material and symbolic production, and the concurrent construction, of a territory.

However, Beijing's historical claims are also not fully legitimate in terms of possession of and authority over the islands, which was occasional. Despite the voluminous dossier filed by the Chinese authorities, the records are vague and incomplete, and do not provide compelling evidence of continuing occupation and effective administration. ${ }^{37}$

The claim that the four island groups were undeniably under Chinese control is further contradicted by an official Chinese government report published in 1928. The report describes the Paracel Islands (Xisha Qundao in Chinese) as the southernmost delineation of the national territory, without mentioning the Spratly Islands. ${ }^{38}$ The whole "time immemorial" claim is even harder to justify if we consider the implementation of the U-shaped line. The drawing of the line dates back to 1947, and does not result from centuries of control over the islands but from Chiang Kai-shek's ambition. This led, in the midst of the civil war, to the Kuomintang's issuing of the map on which the South China Sea was enclosed by the U-shaped line of II dashes. $^{39}$

Almost all the historical evidence produced by the Chinese government is circumstantial and hardly unquestionable, despite Beijing's declarations. Furthermore, if China's claims can be justified on a historical basis, then the same approach might also apply to other similar claims. Vietnam and the

37. The most recent case is the Positional Paper on the South China Sea issued by the Chinese government after the Arbitral Tribunal's award on the China v. Philippines South China Sea Arbitration. For a detailed account on the vagueness of the Chinese historical account, see Bill Hayton, "When Good Lawyers Write Bad History: Unreliable Evidence and the South China Sea Territorial Dispute."

38. Mark J. Valencia, Jon M. van Dyke, and Noel Ludwig, Sharing the Resources of the South China Sea (The Hague: Martinus Nijhoff, 1997), 23.

39. The original U-shaped line was made up of II dashes. In I953, after the end of the Civil War, the newborn PRC revisited the map and reduced the U-shaped line to nine dashes by erasing two dashes in the Gulf of Tonkin. 
Philippines base their historical claims on their past empire and political structure, respectively. If the Chinese position seems stronger, this is mainly because of the country's status and power resources, not because its claim is universally acceptable from a legal standpoint. But this representation of Chinese history has quickly become a source of legitimation for certain segments of civil society and for some pressure groups. The next part of the article aims to describe China's historical narration, and the building of a maritime collective memory based on the mythology of Zheng He's journeys.

\section{ZHENG HE'S VOYAGES AND THE BUILDING OF THE CHINESE MARITIME HERITAGE}

Beijing's irredentist stance has become an important political tool for the ruling elite, even though it lacks solid popular appeal. The main reason behind this lack of inclusion might be the asymmetry between strategic purpose and popular narration. The South China Sea issue has not only been portrayed as a question of historical rights and justice, but it also represents an important geopolitical asset that China is not willing to negotiate with other claimants.

To garner stronger and wider mass support, the CCP needed to engage civil society in a more empathizing narration, designed to awaken the memory of a glorious past and create expectations that supported the party-state's political objectives and strategy. China considered itself a continental power for centuries, and this inclination persisted during Mao Zedong's rule. With the inception of Deng Xiaoping's era in 1978 a new set of political and economic exigencies arose, which prompted the party to rethink its traditionally land-based strategy. During the I990s China experienced impressive economic growth, which persuaded its leaders to reassess the security of the regional commercial maritime lanes in order to safeguard the country's "peaceful rise" through economic development. ${ }^{40}$ As mentioned above, the communist elite has relied on history to compensate for the lack of maritime tradition. Accordingly, Deng and his successors started to work on a new cultural glue able to unite Chinese society in the direction of seagoing pursuits. ${ }^{41}$ 


\section{IN THE NAME OF PEACE: THE CREATION OF A NEW MARITIME NARRATIVE}

The seven voyages of Fleet Admiral Zheng He, stretching as far as Arabia and East Africa and conducted between I405 and I433, and his great popularity both in China and in Southeast Asia, helped the PRC reorient its citizens toward the sea. Zheng He's expeditions were not aimed at conquering lands and subjugating people. They were primarily peaceful journeys of diplomacy, discovery, and trade, with a mandate to spread overseas the knowledge of the Yongle Emperor's (r. I402-24) majesty and virtue. ${ }^{42}$

The use of force was considered only in specific situations. Apart from routine counter-piracy operations, Zheng He's fleet used force only in support of loyal tributary kingdoms. ${ }^{43}$ As a result, these expeditions were certainly aimed at safeguarding imperial interests, but their pacific outlook is probably the most exploitable outcome for the current Chinese government. Thus, in the early 2000s, Chinese officials started to build a new maritime narrative around the peaceful aspects of Zheng's voyages, which gradually become a paradigm of Beijing's maritime posture.

In this regard, Erik Swyngedouw's research on hydro-social territory and waterscape, even if mainly focused on the urban environment, becomes a useful theoretical tool for understanding how the Chinese political elite planned to use the South China Sea as their very own political proscenium. Accordingly, the South China Sea was progressively pictured as a Chinese lake, "an arena around which socio-spatial power choreographies are enacted and performed," ${ }^{44}$ to solicit deeper involvement from civil society. China needed to show itself as a rising benevolent power to its coastal neighbors, but it also needed a power choreography. Zheng He is an esteemed historical figure across the entire region. This aspect made him the ideal diplomatic tool to reinforce China's regional dependability, good faith, and soft-power policy, but also to increase domestic support for the country's renewed regional strategy.

42. Marwyn S. Samuels, Contest for the South China Sea (New York: Methuen, 1982), $20-22$.

43. Louise Levathes, When China Ruled the Seas: The Treasure Fleet of the Dragon Throne, I405-I433 (New York: Oxford University Press, 1994), II4-I8.

44. Erik Swyngedouw, "Scaled Geographies: Nature, Place, and the Politics of Scale," in Robert McMaster and Eric Sheppard, eds., Scale and Geography Inquiry: Nature, Society and Method (Oxford: Blackwell, 2004), I29-53. 
The year 2005 marked the 6ooth anniversary of Zheng He's first expedition and allowed China to trigger the rebuilding of its maritime heritage. In May 2005 the Chinese State Council set July II as Maritime Day. Minister of Communications Zhang Chunxian declared that the day would enhance the Chinese people's awareness of the importance of navigation and the sea, helping to promote maritime development and maritime industry. ${ }^{45}$

The theme of the first Maritime Day encapsulated the goals set by the government, with the title "Love the motherland, be good friends with neighboring countries, and navigate scientifically." A series of events in Zheng He's honor were organized across the country. Former VicePremier Huang Ju gave the opening address, in which he underlined how these voyages had contributed to the world's understanding of navigation and promoted economic and cultural exchange. ${ }^{46}$ According to Zhang Yesui, former vice-foreign minister, these maritime endeavors promoted the peaceful coexistence of various civilizations, demonstrating China's innate tradition of friendship in international relations.

The Zheng He mythology swiftly became one of the most important catalysts of Chinese maritime soft power. Over the following months a number of events played out in Southeast Asia. In August 2005 a new temple honoring Zheng He was unveiled in Semarang, the capital city of Central Java Province, an area that reportedly saw multiple arrivals by Zheng He's "treasure ships" (bao chuan) over the years. Central Java's Governor Mardiyanto declared that the inauguration should be considered a historical development of Zheng He's ideal of unity, mutual help, and peaceful coexistence. ${ }^{47}$ Singapore celebrated Zheng He with a series of activities, including exhibitions, conferences, and a musical. The final event was a reproduction of Longyamen, an ancient gate destroyed by the British in 1848 , which is believed to have been on the route of one of Zheng He's voyages.

Lim Neo Chian, chief executive of the Singapore Tourism Board, stressed the importance of "celebrating a mariner who was larger than life. He

45. "July II Set as Maritime Day," < china.org>, May 25, 2005, <http://www.china.org.cn/ english/2005/May/129831.htm>.

46. "Anniversary Highlights Peaceful Growth," <china.org >, July I2, 2005, <http://www.china. org.cn/english/culture/134686.htm>.

47. "New Zheng He Temple Unveiled in Samarang," <china.org >, August 3, 2005, <http://www. china.org.cn/english/culture/137215.htm>. 
transcended boundaries in his voyages, these celebrations demonstrate the strong influences that Zheng He left in the region." ${ }^{38}$

If we focus on the lexicon used in these public speeches, we notice a constant selection of words and ideas. The values of peaceful coexistence and development, mutual help and harmony were underlined by both the Chinese and the neighboring officials. Zheng He's pacific approach was presented as an embodiment of Chinese people's peaceful relations with the outside world. ${ }^{49}$ As a result, China successfully achieved two important outcomes for its regional policy. First, it showed itself as a responsible power and reminded the neighboring countries that China once exerted a benign maritime influence over the region. Second, it provided a comprehensive historical narrative that the Chinese people could identify with.

\section{THE SEA OF COOPERATION VERSUS THE WAVES OF IMPERIALISM}

Beijing's skill in promoting the Zheng He mythology also helped it reinforce its domestic authority via the South China Sea. If peaceful influence upon the sea is something embedded in Chinese tradition, then it makes perfect sense to claim control and sovereignty over these waters. This strategic approach was corroborated by the Chinese leadership's foresight.

President $\mathrm{Hu}$ Jintao delivered a noteworthy speech in October 2003, during an official visit to Australia. It advanced an intriguing theory: "The Chinese sailed across vast seas and settled down in what was called 'the southern land,' or today's Australia. They brought Chinese culture here and lived harmoniously with the local people, contributing their proud share to Australia's economy, society and thriving pluralistic society." ${ }^{0}$

In terms of political narration, Hu's words (however short on empirical support) had a double impact. First, at the domestic level, he presented China as a maritime power in the Pacific before the arrival of the Europeans. This rhetoric provided an excellent push for Chinese nationalism and contributed to the building of a new maritime narrative. Second, at the

48. "Singapore Recreates Longyamen to Commemorate Zheng He's Epic Voyages," People's Daily, September 7, 2005, <http://en.people.cn/200509/07/eng20050907_207025.html>.

49. Holmes and Yoshihara, Red Star over the Pacific, I63.

5o. Parliament of Australia, Within China's Orbit? China through the Eyes of the Australian Parliament, 2008, <http://www.aph.gov.au/About_Parliament/Parliamentary_Departments/Parlia mentary_Library/pubs/APF/monographs/Within_Chinas_Orbit>, accessed September 9, 2016. 
international level, $\mathrm{Hu}$ created a distinctly Chinese parallel narrative with Australia's early history, with a new perspective about a purported active role by Ming China.

Accordingly, I agree with James Holmes and recognize that history strongly influences China's outlook on maritime affairs, imbuing Beijing's oceanic aspirations with a sense of destiny. ${ }^{51}$ Zheng He was also presented as a sort of anti-imperialist hero, in spite of his imperial investiture. During his expeditions, Zheng He occupied no land and founded no colony, which gives full expression of the Chinese spirit of harmony. The eunuch admiral's virtues were conjured as a pure expression of Confucian teachings, in contrast to the typical predatory Western behavior personified by Cristopher Columbus and the consequent European colonization of the American continent.

This contrast to Western imperialism has become central in the Chinese ruling elite's dialectic, especially toward countries that experienced European colonialism. In February 2007, President Hu delivered a speech at the University of Pretoria, South Africa, where he described China as a "peaceloving nation" and Zheng He as a man who "brought to the African people a message of peace and goodwill, not swords, guns, plunder or slavery." ${ }^{2}$

The ruling elite and the diplomatic corps actively employ this dichotomous rhetoric to assert that China, unlike the Western colonial powers, is not seeking hegemony. Accordingly, Chinese officials claim that Zheng He's voyages never resulted in the seizure of land or the submission of a people. Furthermore, China's leaders have been working to rebuild their own maritime history on the heroic endeavors of Zheng He, not only to justify the maritime dimension of the nation's peaceful rise but also to cater to rising domestic nationalism in China regarding the South China Sea dispute.

Within the context of this article, the whole process of beatification of Zheng He as a seminal Chinese and world figure is thus meant to instill in the population the knowledge and the awareness of their maritime heritage.

51. Holmes and Yoshihara, Red Star over the Pacific, I62.

52. Hu Jintao, "Enhance China-Africa Unity and Cooperation to Build a Harmonious World," Speech at University of Pretoria, South Africa, February 7, 2007, <http://www.fmprc.gov.cn/mfa eng/wjdt_665385/zyjh_665391/t298174.shtml>, accessed September Io, 2016. 


\section{POPULAR MOBILIZATION AND THE PARTY-STATE'S EFFORTS AT CONTROL}

Recalling Zerilli's idea of the space of appearance, the political dimension of this space can be enforced "only so long as people are engaged in speech and action." ${ }^{53}$ China's strategy has gained solid popular participation, channeled through the opening of many commemorative museums and shrines. The mounting patriotic enthusiasm, especially among younger citizens, has produced an interesting but potentially hazardous output. As a result of the progressive engagement of both public opinion and civil society in this historical rebranding, a growing number of citizens have asked the government to be more assertive about the nation's maritime interests. ${ }^{54}$

The ruling elite has the responsibility to protect and nourish the Chinese national identity, but it also has to control how and how forcefully nationalist fervor is expressed. Daniel Lynch described national spirit as something that "penetrates every aspect of the nation's life and culture, and expresses itself through every kind of concrete, living formation," including myths, literature, and outstanding personages such as Zheng He. ${ }^{55}$

To pursue their strategic objectives, top Chinese officials needed to influence the people's sense of belonging, expanding it toward a maritime dimension. Since the establishment of Maritime Day in 2005, China has embraced numerous public meetings, think tanks, and NGOs focused on the South China Sea issue. The NGO and political activism environment is probably the most significant angle of this trend. For example, besides the customary rallies and marches, a growing number of activists have started to plan maritime demonstrations reiterating Chinese sovereignty over the islands of the South China Sea.

In November 2013, a Hong Kong-based group of I3 people arranged a "fishing trip" to the Spratly Islands. When asked about their itinerary, one

53. Linda M. G. Zerilli, Feminism and the Abyss of Freedom (Chicago, IL: University of Chicago Press, 2005), 20.

54. For a brief overview, see Linh Tong, "The Social Media 'War' Over the South China Sea," The Diplomat, July 16, 2016, < https://thediplomat.com/2016/o7/the-social-media-war-over-thesouth-china-sea/>; and Zheping Huang and Echo Huang, "China's citizens are livid at the South China Sea ruling because they've always been taught it is theirs," Quartz, July I3, 2016, < https://qz. $\mathrm{com} / 730669 /$ chinas-citizens-are-livid-at-the-south-china-sea-ruling-because-theyve-always-beentaught-it-is-theirs/>.

55. Daniel C. Lynch, "Securitizing Culture in Chinese Foreign Policy Debates: Implications for Interpreting China’s Rise," Asian Survey 53:4 (2013), 639. 
of the activists answered, "If there are no fish at Nansha, then we will go anywhere within Chinese territory where there are fish, so we can't say right now where the most amount of fish are." ${ }^{56}$ After two days of negotiations with local authorities, the group was denied permission to leave Hong Kong's Victoria Harbor, supposedly for safety reasons. The same group of activists eventually reached the Senkaku/Diaoyu Islands in the East China Sea, where they were arrested by Japanese authorities and released after a few days.

The rising assertiveness of public opinion might lead the government to step back from its strategy, because the leaders may have applied praise of Zheng He and the consequent maritime stimulus too heavily. China has built a new maritime tradition and an effective domestic dialectic on the Zheng $\mathrm{He}$ mythology. The main challenge for Beijing is probably staying in control of this process and not to be overrun by public opinion.

\section{CONCLUSIONS}

In this article I have argued that China has embraced a maritime rebranding process to reinforce its supremacy in the South China Sea. This strategy has been planned and implemented systematically by the ruling elite, and has garnered astonishing support from civil society and public opinion. The Chinese historical claim over the South China Sea has strong domestic significance, but it needed more-captivating rhetoric to penetrate into the collective consciousness. Zheng He has proved to be a surprisingly useful asset for Beijing's strategy, permitting it to channel an old, but newly created, maritime mythology for the present day.

Since the inception of Maritime Day in 2005, citizens have thronged museums and shrines dedicated to the eunuch admiral's travels. China's cultural and strategic maritime rebranding has bolstered the domestic legitimacy of its claim in the South China Sea, but the effectiveness of the campaign has also produced a more demanding citizenry that asks for a more assertive government to manage maritime sovereignty.

The Chinese leaders may have underestimated the effects of this strategy, but it undeniably created a more cohesive popular affinity with the South China Sea, which is now seen as an integral part of the inviolable national

56. "Hong Kong Activists Head to Spratlys for 'Fishing' Trip," Straits Times, November 13, 2013, $<$ http://www.straitstimes.com/asia/hong-kong-activists-head-to-spratlys-for-fishing-trip>. 
territory. The idea of water appropriation might be applied in this case, despite the oceanic scope, because the South China Sea, in the view of many, is comparable to a Chinese lake, and both government and public opinion will not relinquish a single drop of their waters. Consequently, blue waters might be considered an integral part of the national territory. The progressive territorialization of the South China Sea is a fundamental part of this strategy, and China has successfully influenced and controlled actions in, interactions with, and access to its maritime "province" by asserting and enforcing its control over this geographic area.

Empirical evidence shows that Beijing's process of nationalization and territorialization of the waters hinges on its ongoing nation-building process. The U-shaped line is taken as a defined maritime border of Chinese territory, despite the lack of international recognition. China has strengthened its administrative control over the islands and the waters, shaped the territory by enlarging some islands and building both military and civil facilities on them, planned and enforced a unilateral fishing ban, and proposed agreements for oil and gas exploitation.

All these decisions have reinforced the idea of territoriality, because they showed how China exercises its social power over the water and natural resources. Beijing's efforts also transformed into existence a set of new and effective interactions aimed at shaping the maritime environment, reinforced by a constant production of material and symbolic inputs that have progressively led to the highest level of appropriation. 